\title{
Selection of a suitable data set and model for the genetic evaluation of the linear description of conformation and type description in Old Kladruber horses
}

\author{
Luboš Vostrý1,2, Karel Mach' and Josef Přiby|2 \\ ${ }^{1}$ Faculty of Agrobiology, Food and Nature Resources, Czech University of Life Sciences, Prague, Czech Republic, \\ ${ }^{2}$ Institute of Animal Production, Prague - Uhř́něves, Czech Republic
}

\begin{abstract}
The objective of this paper was to select a suitable data subset and statistical model for the estimation of genetic parameters for 36 traits of the linear type in 977 Old Kladruber horses. Two subsets were tested to identify a suitable subset for analysis. One subset included repeated evaluation of certain individuals, whereas the other did not. The most suitable subset included repeated evaluation $(n=1390)$. The selection of a suitable model was made from 4 candidate models. These models comprised a number of random effects (direct individual effect and animal permanent environmental effect of the animal) and a number of fixed effects (colour variant, stud, colour variant $\times$ stud interaction, sex, age at description, year of birth, year of description). The model was selected based on the Akaike information criterion (AIC, Akaike 1974), residual variance and heritability coefficient. The model that included colour variant, stud, colour variant $\times$ stud interaction, sex, age at description, and year of description as fixed effects and direct individual and animal permanent environment as random effects was the most suitable model for the estimation of genetic parameters and for the subsequent estimation of breeding values.
\end{abstract}

Keywords: horse, genetic parameters, animal model, REML

\section{Introduction}

The Old Kladruber horse, an endangered breed, can legitimately claim a lineage in the Czech Republic that spans more than 400 years. The breeding population is located in the stud Kladruby (grey variety) and Slatiňany (black variety) of the National Stud Kladruby nad Labem and in private studs in central Bohemia and the southern parts of Moravia. The differences between the varieties result from the distinct development of both varieties after 1918, i.e., the year in which the Czechoslovak Republic declared its independence and the AustroHungarian monarchy fell. Until 1918, the Old Kladruber horse was bred for the ceremonial use of the imperial court in Vienna and the clerical hierarchy. These institutions were no longer interested in these horses after 1918. The black variety almost became extinct during the period from 1925 to 1940. From the beginning of the 1940s to the mid-1980s, an extensive project was pursued to save the black variety. After 1945, the black variety was bred in the stud of Slatiňany, whereas the grey variety was kept in the stud of Kladruby. Until that time, both varieties were bred separately. After the 1970s, the ownership of the Old Kladruber 
horses expanded to state and private farms. More than one-half of the breed (grey and black horses) is currently in private ownership.

The Old Kladruber horse, with the original cold-blood horses in the Czech Republic (the Silesian Noriker, the Noriker and the (zech-Moravian Belgian horse), belongs to the group of endangered horse breeds in the Czech Republic (Jakubec et al. 2009, Vostrý et al. 2011a). The objective of breeding is to maintain genetic diversity and variability in these populations.

The system of linear description is used routinely, primarily in cattle. A number of analyses of cattle were performed using this system (Brotherstone 1994, Němcová et al. 2011). In horses, body conformation was generally evaluated with a scoring system, whereas linear description was introduced at a later time. The linear description and description of the morphological features in horse breeds was studied previously, e.g., by Jakubec et al. (1999, 2007) in the Old Kladruber horse, by Pretorius et al. (2004) in Friesian horses, Zechner et al. (2001) in Lipizzan horses, Molina et al. (1999) in Andalusian horses, Samoré et al. (1997) in the Haflinger breed and by Van Bergen \& Van Arendonk (1993) in the Shetland pony. Schlote et al. (2002) used computer technology to study the development of the standardisation of the evaluation of type in horses. Halo et al. (2008) evaluated the results of efficiency tests of Slovak warm-blood horses. Wolc \& Balińska (2010) and Borowska et al. (2011) estimated the effect of the inbreeding level on basic biometrical measurements in the Polish Konik and on the 100-day stationary performance test in Polish warm-blood stallions.

This paper is a follow-up to a number of previous analyses of the genetic resources of horse breeds in the Czech Republic (e.g. Hofmanová \& Majzlík 2006, Jakubec et al. 2009, Vostrý et al. 2011a, b, c, d).

The objective of this study was to select a suitable model and data set for the estimation of genetic parameters and the estimation of breeding value for linear type description in Old Kladruber horses.

\section{Materials and methods}

Linear type description in the Old Kladruber horse was performed in accordance with the Jakubec et al. (1999) methodology. In each individual, 36 traits were described (Table 2). These traits can be divided into 4 groups. Each group comprises the traits described in a particular part of the body, i.e., the front, body, rear and limbs. For the description of trait development, a linear scale from 1 to 9 was used. Data for the estimation of the breeding value of linear type description in the Old Kladruber horse were obtained from the stud book of the Old Kladruber Horse (www.nhkladruby.cz). The data set for genetic parameters comprised 977 individuals during a period of 16 years (1990-2006). The 64 stallions in the data set sired from 2 to 42 offspring. On average, each stallion had 15 offspring. Repeated measurements on $30 \%$ of the animals were included in the database (1 390 observations in all). For this reason, the appropriateness of the repeated description of individuals for the estimation of genetic parameters and breeding value was tested.

The selection of a suitable data set (with or without replication) and a model for the estimation of the genetic parameters and breeding value for each trait was tested with the REML method. These one-trait BLUP animal models are based on the methodology in Jakubec et al. (2007) (Table 1). 
Table 1

Models

\begin{tabular}{lcccccccccccc}
\hline & Var & Breed & Sex & AgeD & YearB & YearD & B $\times$ V & Fam & Lin & A & Pe & $\begin{array}{c}\text { No of } \\
\text { observations }\end{array}$ \\
\hline Model 1 & F & F & F & F & F & & F & R & R & R & & 977 \\
Model 2 & F & F & F & F & F & & F & R & R & R & R & 1369 \\
Model 3 & F & F & F & F & F & & F & & & R & R & 1369 \\
Model 4 & F & F & F & F & & F & F & & & R & R & 1369 \\
\hline
\end{tabular}

Var: effect of colour variant (white, black), Breed: effect of breed (National stud, private herds), Sex: effect of sex, AgeD: effect of age at description, YearB: effect of year of birth, YearD: effect of year of description, $B \times V$ : breed $\times$ colour variant interaction, Fam: effect of family, Lin: effect of line, A: effect of individual, Pe: effect of permanent environment on an individual, F: fixed, R: random

Models 1 and 2 were based on the evaluation of Old Kladruber stallions by the least-squares method (Jakubec et al. 2007, Čapková 2008).

It is assumed that the effects are mutually independent within the particular traits. It is further assumed that the effects have a normal distribution with zero mean and variance $\sigma^{2}$ :

$$
\begin{aligned}
& V(a)=\boldsymbol{A} \sigma_{a}^{2} \\
& V(a)=I \sigma_{p e}^{2} \\
& V(a)=I \sigma_{e}^{2}
\end{aligned}
$$

where $\sigma_{a}^{2}$ is the additive genetic variance of the direct effect, $\sigma_{p e}^{2}$ is the variance of the effect of the animal's permanent environment, $\sigma_{e}^{2}$ is the variance of the effect of residual error, $A$ is the relationship matrix, and $I$ is the identity matrix.

The description of the traits for the linear type description for all individuals was performed by a single classifier. For this reason, the effect of the classifier was not included in the model equation. The influence of the maternal effect on the body conformation of an individual was not included in the experiment due to the low number of individuals per mare.

The pedigree set contained 5 generations of ancestors and 1556 individuals. Unknown parents were included in 1 group: the »phantom parents« group.

REMLF90 software (Misztal et al. 2002) was used for the estimation of variance-covariance components. An estimate of $h^{2}$, the direct heritability $\left[h^{2}=\sigma_{a}^{2} / \sigma_{y}^{2}\right]$, was derived from the estimated variance and covariance components.

The appropriateness of the models and data set was tested based on the values of residual variance $\left(\sigma_{e}^{2}\right)$ and the AIC (Bozdogan 2000):

$$
A / C=-2 \log L(\theta)+2 d
$$

where $\log L(\theta)$ is the logarithm of the likelihood function value and $d$ is the number of free parameters in the model.

\section{Results and discussion}

Selection of a suitable model

In all the models tested, fixed effects explained from 15 to $34 \%$ of the total variability in the particular traits. The models including the fixed effect of the year of description explained 
approximately $2 \%$ more of the total variability than the models including the effect of the year of birth. All of the fixed effects tested were statistically significant. Jakubec et al. (2007) found estimates identical to these values. The significance of herd $\times$ variant interaction $(P<0.0001)$ is justified in the history of Old Kladruber horse breeding. From 1945 to 2005, both variants (white and black horses) were raised separately, and matings between grey and black horses occurred only on occasion. Moreover, from ca. 1990 to 2000, matings between horses in the National Stud and in private herds were limited. This practice caused the separation of these two subpopulations.

The estimations of the values of residual variance $\left(\sigma_{e}^{2}\right), \mathrm{AIC}$ and heritability coefficients $\left(\mathrm{h}^{2}\right)$ are shown in Table 2. The comparison of models 1 and 2, where model 2 included repeated measurements on $30 \%$ of the individuals (model 1 did not include any repeated measurements), shows that the value of residual variance decreased from model 1 to model 2 for the majority of the traits $(54 \%)$, whereas the coefficient of heritability simultaneously increased. Variability decreased in $14 \%$ of the traits. This decrease caused a decrease in both the values of the residual variance and the values of the heritability coefficient. In contrast, higher values of the residual variance and heritability coefficient were estimated in model 2 for $6 \%$ of the traits. A reduction in residual variability accompanied by an increase in the value of the heritability coefficient indicated the greater appropriateness of the data set with repeated measurements. Repeatability $\left(r_{m}\right)$, the sum of $h^{2}$ and the ratio of the permanent environment reflect differences in the accuracy of measurements of the particular traits and the development of the linear type description in the Old Kladruber horse at the time. The repeatability coefficient ranged from 0.07 to 0.76 . The low values of the repeatability coefficient ( 0.07 and 0.09 ) were estimated for traits that may be influenced by the posture of the horse, e.g., shoulder length and shoulder slope. Similar conclusions were drawn by Zechner et al. (2001). In most cases, the lowest values of repeatability were found for traits with a low value of the coefficient $h^{2}$. The lower values of the ratio of the permanent environment indicate a lower accuracy of measurements of the particular traits or a large change in development of the linear type description with the age of the animal.

Model 3, which did not include the random effects of family and line, had lower values of AIC in most traits compared with model 2. Higher values of AIC were estimated only in one trait (neck topside). The estimates of the residual variance in most traits had identical values for models 2 and 3. The only exceptions were the traits neck topside and withers length, for which higher values of residual variance were estimated by model 3. Model 3, which had lower values of AIC than model 2 with identical values of residual variance, had higher values of the heritability coefficient compared with model 2 . These lower values for AIC in model 3, which did not include the random effects of family and line, demonstrate the greater suitability of model 3 compared with model 2 . For these reasons, the random effects of line and family, in which a certain effect of cytoplasmic inheritance or genetic imprinting was assumed, were not included in the model for further evaluation. These results are in agreement with the conclusions published by Vostrý et al. (2011d) in Czech Draft horses and the findings of Vostrý et al. (2011b) from an analysis of the sire line of Old Kladruber horse based on microsatellites. A common belief among those with interests in horses is that the male influence is very important. This influence would appear to be received directly from the ancestral paternal lineage. However, additive genetic value is theoretically the parental 
average with an added random perturbation resulting from the effects of Mendelian sampling (Falconer \& Mackay 1996). As stated, the model considering the line effect only incorporates the genetic background furnished by the $Y$ chromosome. This contribution is a small proportion of the total genetic effect, as shown by its low significance.

Table 2

The values of AIC, residual variance and coefficients of heritability

\begin{tabular}{|c|c|c|c|c|c|c|c|c|c|c|c|c|c|}
\hline \multirow[t]{2}{*}{ Traits } & \multirow[t]{2}{*}{ Traits } & \multicolumn{3}{|c|}{ Model 1} & \multicolumn{3}{|c|}{ Model 2} & \multicolumn{3}{|c|}{ Model 3} & \multicolumn{3}{|c|}{ Model $4^{*}$} \\
\hline & & $\mathrm{AIC}$ & $\sigma_{\mathrm{e}}^{2}$ & $h^{2}$ & AIC & $\sigma_{\mathrm{e}}^{2}$ & $h^{2}$ & AIC & $\sigma_{\mathrm{e}}^{2}$ & $h^{2}$ & AIC & $\sigma_{\mathrm{e}}^{2}$ & $h^{2}$ \\
\hline \multicolumn{14}{|l|}{ Front } \\
\hline HW & Height at withers & 3835 & 1.81 & 0.54 & 4666 & 1.46 & 0.54 & 4662 & 1.46 & 0.55 & 4668 & 1.09 & 0.57 \\
\hline $\mathrm{HF}$ & Heftiness & 3391 & 1.29 & 0.45 & 4204 & 1.06 & 0.44 & 4201 & 1.08 & 0.46 & 4210 & 1.00 & 0.49 \\
\hline $\mathrm{HP}$ & Head profile & 3380 & 0.81 & 0.68 & 4687 & 0.75 & 0.63 & 4683 & 0.75 & 0.64 & 4664 & 0.71 & 0.65 \\
\hline NL & Neck length & 2996 & 1.16 & 0.12 & 4320 & 1.18 & 0.09 & 4317 & 1.18 & 0.10 & 4310 & 1.17 & 0.11 \\
\hline NTe & Neck tethering & 2835 & 0.95 & 0.16 & 3999 & 0.74 & 0.13 & 3995 & 0.74 & 0.13 & 3987 & 0.73 & 0.12 \\
\hline NTo & Neck topside & 3791 & 2.56 & 0.18 & 5438 & 1.95 & 0.26 & 5441 & 1.96 & 0.31 & 5434 & 1.91 & 0.33 \\
\hline WL & Wither length & 3539 & 2.06 & 0.13 & 4933 & 1.00 & 0.16 & 4931 & 1.09 & 0.17 & 4937 & 1.10 & 0.19 \\
\hline WH & Wither height & 3171 & 1.35 & 0.17 & 4471 & 1.01 & 0.20 & 4469 & 1.01 & 0.21 & 4480 & 0.99 & 0.23 \\
\hline \multicolumn{14}{|l|}{ Body } \\
\hline $\mathrm{TL}$ & Topline length & 3182 & 1.23 & 0.29 & 4419 & 0.93 & 0.30 & 4415 & 0.93 & 0.30 & 4390 & 0.87 & 0.28 \\
\hline TV & Topline vault & 2278 & 0.49 & 0.22 & 3297 & 0.39 & 0.24 & 3294 & 0.39 & 0.26 & 3281 & 0.37 & 0.28 \\
\hline $\mathrm{LL}$ & Loin length & 2983 & 1.26 & 0.02 & 4206 & 1.01 & 0.09 & 4202 & 1.01 & 0.10 & 4201 & 1.01 & 0.10 \\
\hline LV & Loin vault & 2948 & 1.09 & 0.14 & 4183 & 0.98 & 0.14 & 4179 & 0.98 & 0.14 & 4119 & 0.86 & 0.15 \\
\hline $\mathrm{SL}$ & Shoulder length & 2322 & 0.61 & 0.02 & 3511 & 0.68 & 0.05 & 3508 & 0.67 & 0.06 & 3441 & 0.64 & 0.07 \\
\hline SS & Shoulder slope & 2849 & 1.09 & 0.02 & 4151 & 1.08 & 0.05 & 4147 & 1.08 & 0.05 & 4111 & 1.02 & 0.05 \\
\hline $\mathrm{ChG}$ & Chest girth & 4289 & 3.73 & 0.38 & 5115 & 1.42 & 0.38 & 5111 & 1.42 & 0.38 & 5124 & 1.47 & 0.40 \\
\hline $\mathrm{ChL}$ & Chest length & 2788 & 0.82 & 0.27 & 3976 & 0.77 & 0.23 & 3972 & 0.77 & 0.24 & 3967 & 0.76 & 0.23 \\
\hline ChW & Chest width & 3187 & 1.28 & 0.25 & 4484 & 0.95 & 0.29 & 4480 & 0.95 & 0.28 & 4441 & 0.85 & 0.31 \\
\hline ChD & Chest depth & 3150 & 1.16 & 0.29 & 4483 & 1.10 & 0.26 & 4481 & 1.10 & 0.27 & 4483 & 1.09 & 0.27 \\
\hline BW & Breast width & 3198 & 1.27 & 0.27 & 4577 & 1.03 & 0.30 & 4573 & 1.03 & 0.29 & 4538 & 0.93 & 0.33 \\
\hline \multicolumn{14}{|l|}{ Rear } \\
\hline $\mathrm{CrL}$ & Croup length & 2800 & 0.98 & 0.09 & 4038 & 0.90 & 0.08 & 4034 & 0.90 & 0.08 & 4040 & 0.91 & 0.08 \\
\hline $\mathrm{CrW}$ & Croup width & 3064 & 1.01 & 0.35 & 4400 & 1.05 & 0.32 & 4397 & 1.05 & 0.31 & 4253 & 0.72 & 0.35 \\
\hline $\mathrm{CrS}$ & Croup shape & 2924 & 0.94 & 0.26 & 4173 & 0.70 & 0.32 & 4171 & 0.70 & 0.33 & 4169 & 0.68 & 0.35 \\
\hline $\mathrm{CrP}$ & Croup profile & 3203 & 1.30 & 0.26 & 4475 & 1.12 & 0.23 & 4471 & 1.12 & 0.23 & 4411 & 0.99 & 0.25 \\
\hline TT & Tail tethering & 3102 & 1.33 & 0.10 & 4476 & 0.89 & 0.13 & 4473 & 0.89 & 0.15 & 4474 & 0.89 & 0.17 \\
\hline \multicolumn{14}{|l|}{ Limbs } \\
\hline FIFV & Forelimbs - front view & 2437 & 0.64 & 0.12 & 3607 & 0.56 & 0.07 & 3603 & 0.56 & 0.07 & 3602 & 0.56 & 0.08 \\
\hline FiSV & Forelimbs - side view & 3749 & 2.78 & 0.07 & 5361 & 2.39 & 0.09 & 5357 & 2.39 & 0.10 & 5366 & 2.39 & 0.10 \\
\hline $\mathrm{FtSV}$ & Foretoes - side view & 2494 & 0.63 & 0.20 & 3765 & 0.64 & 0.14 & 3762 & 0.64 & 0.16 & 3707 & 0.60 & 0.17 \\
\hline FtL & Foretoe length & 2500 & 0.74 & 0.14 & 3737 & 0.77 & 0.18 & 3733 & 0.77 & 0.19 & 3653 & 0.71 & 0.21 \\
\hline FhSV & Forehoofside view & 2671 & 0.80 & 0.16 & 4080 & 0.87 & 0.13 & 4077 & 0.87 & 0.13 & 3864 & 0.62 & 0.16 \\
\hline FhW & Forehoof width & 2648 & 0.63 & 0.35 & 3780 & 0.58 & 0.39 & 3778 & 0.58 & 0.40 & 3776 & 0.58 & 0.41 \\
\hline FhS & Forehoof size & 1922 & 0.37 & 0.10 & 2646 & 0.33 & 0.11 & 2644 & 0.33 & 0.12 & 2592 & 0.32 & 0.14 \\
\hline HLSV & Hind limbside view & 2616 & 0.82 & 0.05 & 3750 & 0.54 & 0.01 & 3748 & 0.54 & 0.03 & 3704 & 0.51 & 0.05 \\
\hline HLBV & Hind limbrear view & 2437 & 0.66 & 0.08 & 3439 & 0.56 & 0.02 & 3436 & 0.56 & 0.04 & 3401 & 0.54 & 0.04 \\
\hline FIFS & Fetlock from the side & 2145 & 0.54 & 0.00 & 3285 & 0.54 & 0.02 & 3283 & 0.54 & 0.05 & 3194 & 0.47 & 0.06 \\
\hline LF & Length of the fetlock & 2606 & 0.88 & 0.09 & 3765 & 0.78 & 0.17 & 3761 & 0.78 & 0.17 & 3650 & 0.63 & 0.20 \\
\hline AHW & Angle of hoof wall & 2412 & 0.66 & 0.15 & 3701 & 0.76 & 0.13 & 3706 & 0.76 & 0.18 & 3550 & 0.58 & 0.20 \\
\hline
\end{tabular}

*Vostrý et al. 2011c

The inclusion of the fixed effect of year of description (model 4) compared with the fixed effect of year of birth (model 3 ) resulted in a decrease in the value of residual variance in most traits $(80 \%)$. In contrast, higher values of residual variance were estimated in model 4 than 
in model 3 for $9 \%$ of the traits. The values of the heritability coefficients for most traits were higher in model 4 than in model 3 or the other two models (models 1 and 2).

These results show that the estimation of genetic parameters, residual variance and AIC values is influenced by the inclusion of repeated evaluation. Therefore, the data set with repeated descriptions of individuals was suitable for use for the estimation of genetic parameters and breeding value, as was model 4, which included the fixed effect of year of description and lacked the random effects of family and line.

The highest estimates of heritability were found for traits describing the front of the body. Other trait groups had lower estimates. The lowest estimates of heritability were found for traits describing the legs. The head profile had the highest heritability coefficient $(0.65)$. The hind limb side view and the hind limb rear view had the lowest heritability coefficients (both 0.05). These results show that many linearly scored traits were moderately heritable. The moderate heritabilities estimated for the traits included in linear type description indicate that the genetic improvement of these traits would be possible.

Jakubec et al. (2009) reported values of heritability in the Old Kladruber horse similar to the values found by this study. However, differences between these two works may be the result of different sample sizes. Jakubec et al. (2009) used a sample of only 490 individuals. In Andalusian horses, Molina et al. (1999) estimated an $\mathrm{h}^{2}$ value for height at withers (0.58), which was identical to the value found by this study, but estimated a higher $\mathrm{h}^{2}$ value for chest width (0.56). In Bardigiano horses, Fioretti et al. (2005) reported heritabilities similar to the values found by this study for the corresponding traits. In the Lipizzan horse, Zechner et al. (2001) estimated values of the heritability coefficients for height at withers (0.52) and chest width (0.36) similar to those found by this study, but he estimated a higher $h^{2}$ value for croup length and lower $\mathrm{h}^{2}$ values for neck length (0.05) and chest girth (0.25). Baban et al. (1998) calculated lower values for a number of heritability coefficients, as did the authors previously cited. The reason for these differences may be that the traits were evaluated in different breeds and in different countries.

The results of this study showed that model 4, which included the fixed effect of year of description, was the most suitable for the estimation of genetic parameters and subsequently of breeding values, as was the data set that included repeated evaluation.

\section{Acknowledgement}

This work was supported by the Ministry of Education, Youth and Sports of the Czech Republic (Project No. MSM 6046070901) and by the Ministry of Agriculture of the Czech Republic (Project No. MZE 0002701404).

\section{References}

Akaike H (1974) A new look at the statistical model identification. IEEE Transactions on Automatic Control 19, 716-723

Baban M, Rastija T, Caput P, Knežević I, Stipić N (1998) Estimation of heritability of Lipizzaner horses for morphological traits by means of various methods. Czech J Anim Sci 43, 299-303 
Borowska A, Wolc A, Szwaczkowski T (2011) Genetic variability of traits recorded during 100-day stationary performance test and inbreeding level in Polish warmblood stallions. Arch Tierz 54, 327-337

Bozdogan H (2000) Akaike's information criterion and recent developments in information complexity. J Math Psychol 44, 62-91

Brotherstone S (1994) Genetic and phenotypic correlations between linear type traits and production traits in Holstein - Friesian dairy-cattle. Anim Prod 59,183-187

Čapková Z (2008) Analysis of body measurements in sire lines and dame families of Old Kladruby Horses. J Agrobiol 25, 13-15

Falconer DS, Mackay TFC (1996) Introduction to quantitative genetics. 4th ed. Longman Group Ltd, Harlow, UK

Fioretti M, Catalano AL, Rosati A, Martuzzi F (2005) Bardigiano Horse selection: a genetic global index for linear type traits. In: Bodò I, Alderson L, Langlois B (eds.) Conservation genetics of endangered horses breeds. EAAP Scientific Series 116, 147-154

Halo M, Mlynek J, Strapák P, Massányi P (2008) Genetic efficiency parameters of Slovak warm-blood horse. Arch Tierz 51, 5-15

Hofmanová B, Majzlík I (2006) [The occurrence and quantification of melanoma in grey Old Kladruber horses with the respect for line origin]. Acta fytotechnica et zootechnica 9, 40-42 [in Slovak]

Jakubec V, Schlote W, Jelínek J, Scholz A, Záliš N (1999) Linear type trait analysis in the genetic resource of the Old Kladrub Horse. Arch Tierz 42, 215-224

Jakubec V, Rejfková M, Volenec J, Majzlík I, Vostrý L (2007) Analysis of linear description of type traits in the varieties and studs of the Old Kladrub horse

Jakubec V, Vostrý L, Schlote W, Majzlík I, Mach K (2009) Selection in the genetic resource: genetic variation of the linear described type traits in the Old Kladrub horse. Arch Tierz 52, 343-355

Misztal I, Tsuruta S, Strabel T, Auvray B, Druet T, Lee DH (2002) BLUPF90 and related programs (BGF90). In: Proc. 7th World Congress on Genetics Applied to Livestock Production, Montpellier, France, 33, 743-744

Molina A, Valera M, Dos Santos R, Rodero A (1999) Genetic parameters of morphofunctional traits in Andalusian horse. Livest Prod Sci 60, 295-303

Němcová E, Štípková M, Zavadilová L (2011) Genetic parameters for linear type traits in Czech Holstein cattle. Czech J Anim Sci 56, 157-162

Pretorius SM, Van Marle-Köster E, Mostert (2004) Description of the Friesian Horse population of South Africa and Nambia. South Africa J Anim Sci 34, 149-157

Samoré AB, Pagnacco G, Miglior F (1997) Genetic parameters and breeding values for linear type traits in the Haflinger horse. Livest Prod Sci 52, 105-111

Schlote W, Jakubec V, Schulz A, Umstätter C, Höhne S, Deschan R, Majzlík I, Záliš N, Volenec J (2002) Investigations on standardizing evaluation of external conformation traits using the Old Kladrub Horse as an example. In: Proc. 7th World Congress on Genetics Applied to Livestock Production, Montpellier, France, 30, 423-426

Van Bergen HMM, Van Arendonk JAM (1993) Genetic parameters for linear type traits in Shetland ponies. Livest Prod Sci, 36, 273-284

Vostrý L, Čapková Z, Přibyl J, Hofmanová B, Vostrá Vydrová H, Mach K (2011a) Population structure of Czech cold-blooded breeds of horses. Arch Tierz 54, 1-9

Vostrý L, Kracíková O, Hofmanová B, Czerneková V, Kott T, Přibyl J (2011b) Intra-line and inter-line genetic diversity in sire lines of the Old Kladruber horse based on microsatellite analysis of DNA. Czech J Anim Sci $56,163-175$

Vostrý L, Přibyl J, Mach K, Majzlík I (2011c) Genetic parameters estimation and breeding values prediction for linear described traits in the Old Kladruber horse. J Anim Feed Sci 20, 338-349 
Vostrý L, Čapková Z, Přibyl J, Mach K (2011d) Analysis of Czech cold-blooded horses: genetic parameters, breeding value and the influence of inbreeding depression on linear description of conformation and type characters. Czech J Anim Sci 56, 217-230

Wolc A, Balińska K (2010) Inbreeding effects on exterior traits in Polish konik horses. Arch Tierz 53, 1-8

Zechner P, Zohman F, Sölkner J, Bodo I, Habe F, Marti E, Brem G (2001) Morphological description of the Lipizzan horse population. Livest Prod Sci 69, 163-77

Received 23 August 2011, accepted 1 December 2011.

Corresponding author:

Luboš Vostrý

email: vostry@af.czu.cz

Czech University of Life Sciences Prague, Kamýcká 129, 16521 Prague 6 - Suchdol, Czech Republic 